IJAMSR 2 (1) www.ijamsr.com CrossRef: https://doi.org/10.31426/ijamsr.2019.2.1.1113

\title{
Scientific Temper of Rural and Urban Senior Secondary School Students
}

\author{
Jan Jahanger ${ }^{1 *}$, Gh Nabi Dar ${ }^{2}$ \\ Research Scholar, University Institute of Education, Sant Baba Bhag Singh University, \\ Jalandhar, Punjab, India.
}

Research Scholar, School of Education, DAVV University, Indore, M.P, India.

Email: janjahangir74@gmail.com

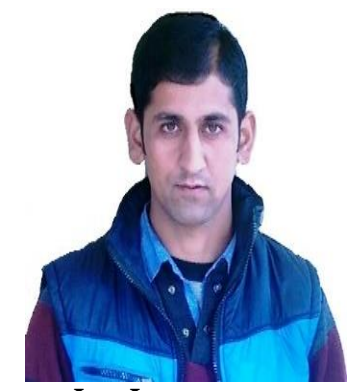

JAN JAHANGER

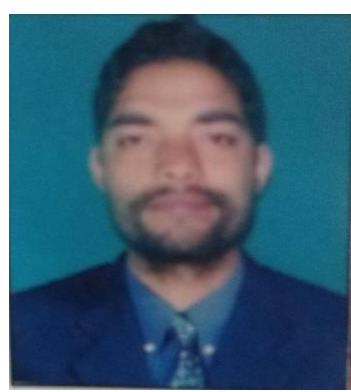

GH NABI DAR

\begin{abstract}
A B S T RA C T
The focus of the present research was to study the scientific temper of rural and urban senior secondary school students of district Baramulla of Jammu and Kashmir. The sample consists of 300 (150 rural and 150 urban) senior secondary school students, selected randomly. The data was collected by using N.A. Nadeem and Showkat Rashid Wani's Scale of scientific temper. The investigator used various statistical techniques viz, mean, S.D., t-test to analyze the data. The statistical data revealed that there is a significant difference between rural and urban senior secondary school students on various dimensions of scientific temper.
\end{abstract}

Citation: Jan Jahanger, Gh Nabi Dar (2019). Scientific Temper of Rural and Urban Senior Secondary School Students. International Journal of Advanced Multidisciplinary Scientific Research (IJAMSR ) ISSN:2581-4281, 2 (1), January, 2019, \# Art.1113, pp $15-20$

Keywords: scientific temper, rural and urban senior secondary school students. 
IJAMSR 2 (1) Www.ijamsr.com CrossRef: https://doi.org/10.31426/ijamsr.2019.2.1.1113

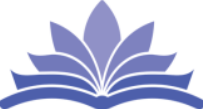

I J A M S R

International Journal of

Advanced Multidisciplinary Scientific Research (IJAMSR) ISSN:2581-4281

\section{Introduction}

Scientific advances over the last fifty years have led to revolutionary changes in health, nutrition and communication, and generally enhancing socioeconomic development and the quality of our lives. The role of science will promise to be greater in the future because of the evermore rapid scientific progress. Our society is becoming increasingly dependent on science and technology. It is essential for the well-being of our society that all citizens develop 'science literacy', an appreciation of science and the benefits of technology. Scientific temper describes an attitude which involves the application of logic and the avoidance of bias. The mental attitude which is behind the method of acquiring reliable and practical knowledge may be called the "Scientific Temper". A scientific temper thus refers to an open, questioning seeking mind. Discussion, argument and analysis are vital parts of scientific temper. Scientific temper is not really the knowledge of a particular subject or theorems and laws that define such a temper. Not all people with knowledge of physics, chemistry, biology or any other subject can be called scientific. A scientific temper refers to an open, questioning seeking mind. A mind seeks truth and accepts it when proved. A mind that is curious to understand 'whys' and 'hows' of life while accepting that all questions may not be fully answerable. Scientific temper describes an attitude which involves the application of logic and the avoidance of bias and preconceived notions.

Almost all the political leaders of Indian freedom movement and social reformers repeatedly emphasized the need to integrate modern Science into Indian culture. In 1937 Gandhi emphasized the need of Science in Nai
Taleem (New Education), he writes: 'Only every handicraft has to be taught not merely mechanically as is done today, but scientifically.

The concept of Scientific Temper was articulated first by Pandit Jawaharlal Nehru in 1946 in his book Discovery of India, referring to it as "a way of life, a process of thinking, a method of acting and associating with our fellow men". The tradition of skepticism and humanism is not new to Indian intellectual tradition. Notably, during the $42^{\text {nd }}$ Constitutional Amendment Act, 1976 of the Indian Constitution an Article $51 \mathrm{~A}$ was inserted, which makes provisions for the fundamental duties prescribed for citizens of India. This Article has a point which declares the role of scientific temper in the following way: "It shall be the duty of every citizen of India to develop the scientific temper, humanism and the spirit of inquiry and reform." (Article 51A, the Constitution of India). Krishnan and Bhuvaneshwari (1990) define scientific temper as one's reactions in his/her life situations as practice of seeing cause and effect relationship of utility of science in daily life functions, adventurousness, experimental bent, intellectual honesty, objectivity, open mindedness challenging blind faith and receptivity to change. A mind seeks truth and accepts it when proved.NCF, 2005 is not the only document that has given directions for developing a scientific temper among the students, but several commissions and committees on education have recommended for inculcating scientific temper, developing the spirit of inquiry and focusing on learning by doing through activity based science teaching in the school curriculum which can play great role in developing a scientific temper. 
IJAMSR 2 (1) Www.ijamsr.com CrossRef: https://doi.org/10.31426/ijamsr.2019.2.1.1113

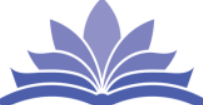

I J A M S R

Objectives of Study

International Journal of

Objectives of Study Investigation:

a) To study, the Scientific Temper of Rural and Urban Secondary School Students.

b) To compare Rural and Urban Secondary School Students on Scientific Temper.

\section{Hypothesis of Study}

The following hypotheses were formulated for the present study:

a) Rural and Urban Secondary School Students differ significantly on Scientific Temper.

\section{Operational Definition of Variables}

Scientific Temper: For the purpose of the present study, Scientific Temper has been operationally defined as the score which the investigator got by administering Prof. Nadeem's and Showkat's Scientific Temper Scale.

\section{Sample}

The sample for the study consisted of 300 secondary school students (150 Rural and 150 Urban students). The sample for the study was selected randomly from the different schools of Baramulla (as Urban district \& rural district). The sample was selected in such a way to ensure that every unit of the population could get an equal chance to be selected in the sample.

\section{Selection and Description of Tools}

The tools for the present study were selected in a manner to achieve an optimum level of confidence by the investigator for the objectives of the study. Since the study principally contained the variable, namely scientific temper, therefore, such tools were decided to be chosen as could validly and reliably measure these variations. The investigator after screening a number of available tests finally selected the Scientific Temper Scale developed by Prof. N.A Nadeem and Showkat Rashid Wani.

\section{Analysis and Interpretation}

By keeping in mind the first objective of this study, the researcher studied the level of scientific temper of senior secondary school students. On the basis of levels as given in the manual of the scales as high, above average, average, below average and poor level. After that the investigator used t-test to find significant differences in scientific temper of senior secondary school students on the basis of locale. Details pertaining to the analysis are being given separately as follows.

\section{Levels of Scientific Temper of Senior Secondary School Students}

In order to examine the level of scientific temper of senior secondary school students of Baramulla, the investigator used scientific temper scale for collecting information from subjects. The scores of the scientific temper scale were calculated and divided into five groups on the basis of values given in the norms of the manual i.e. High Scientific Temper (HST), Above Average Scientific Temper (AAST), Average Scientific Temper (AST), Below Average Scientific Temper (BAST) and Poor Scientific Temper (PST). The results have been presented in the figure 1 . 
IJAMSR 2 (1) www.ijamsr.com CrossRef: https://doi.org/10.31426/ijamsr.2019.2.1.1113

\section{International Journal of \\ I J A M S R \\ Advanced Multidisciplinary Scientific Research (IJAMSR) ISSN:2581-4281}

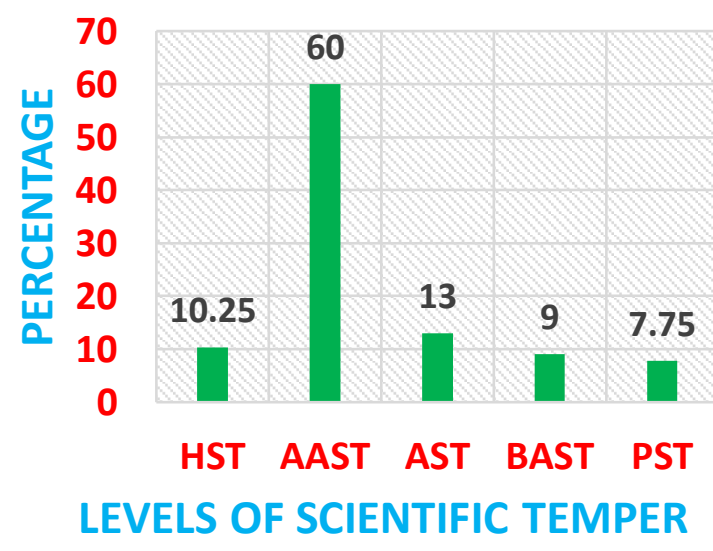

Table 1: Significance of difference between Means of Urban and Rural senior Secondary School students on 'Curiosity' Dimension of Scientific Temper

\begin{tabular}{|c|c|c|c|c|l|}
\hline Group & N & Mean & SD & $\begin{array}{c}\text { t- } \\
\text { value }\end{array}$ & Significance \\
\hline Rural & 150 & 6.87 & 1.07 & \multirow{2}{*}{4.76} & $\begin{array}{l}\text { Significant at } \\
0.00 \text { level }\end{array}$ \\
\hline Urban & 150 & 7.47 & 1.12 & & \\
\hline
\end{tabular}

The above table shows the mean difference between Rural and Urban senior secondary school students on curiosity dimension of scientific temper. The table reveals that there is a significant mean difference between Rural and Urban senior Secondary school students on Curiosity dimension.

As there was a significant mean difference found between Rural and Urban senior secondary school students on Curiosity dimension which confirms that Rural and Urban students are not equally curious to learn the things as compared to urban students.
Table 2: Significance of difference between Means of Urban and Rural senior Secondary School students on 'Open Mindedness' Dimension of Scientific Temper.

\begin{tabular}{|c|c|c|c|c|c|}
\hline Group & N & Mean & SD & $\begin{array}{c}\text { t- } \\
\text { value }\end{array}$ & Significance \\
\hline Rural & 150 & 7.10 & 1.13 & \multirow{2}{*}{0.84} & Insignificant \\
\cline { 1 - 3 } Urban & 150 & 6.99 & 1.26 & & \\
\hline
\end{tabular}

The above table shows the mean difference between Rural and Urban senior secondary school students on the open mindedness dimension of scientific temper. The table reveals that there is no significant mean difference between Rural and Urban senior Secondary school students on open mindedness dimension. As there was no significant mean difference found between Rural and Urban senior secondary school students on an open mindedness dimension which confirms that Rural and Urban students are equally open minded.

Table 3: Significance of difference between Means of Urban and Rural senior Secondary School students on 'Objectivity' Dimension of Scientific Temper.

\begin{tabular}{|c|c|c|c|c|l|}
\hline Group & N & Mean & SD & $\begin{array}{c}\text { t- } \\
\text { value }\end{array}$ & Significance \\
\hline Rural & 150 & 5.25 & 1.28 & \multirow{2}{*}{2.17} & $\begin{array}{l}\text { Significant at } \\
0.05 \text { level }\end{array}$ \\
\hline Urban & 150 & 6.41 & 1.26 & & \\
\hline
\end{tabular}

The above table shows the mean difference between Rural and Urban senior secondary school students on objectivity dimension of scientific temper. The table reveals that there is no significant mean difference 
IJAMSR 2 (1) Www.ijamsr.com CrossRef: https://doi.org/10.31426/ijamsr.2019.2.1.1113

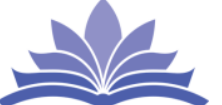

I J A M S R

International Journal of Advanced Multidisciplinary Scientific Research (IJAMSR) ISSN:2581-4281

\begin{tabular}{|c|c|c|c|c|l|}
\hline Group & N & Mean & SD & t-value & Significance \\
\hline Rural & 150 & 4.92 & 1.49 & \multirow{2}{*}{2.85} & $\begin{array}{l}\text { Significant at } \\
0.01 \text { level }\end{array}$ \\
\cline { 1 - 3 } Urban & 150 & 4.46 & 1.73 & & \\
\hline
\end{tabular}

between Rural and Urban senior Secondary school students on objectivity dimension. As there was no significant mean difference found between Rural and Urban senior secondary school students on objectivity dimension which confirms that Rural and Urban students are equally objective.

Table 4: Significance of difference between Means of Urban and Rural senior Secondary School students on 'Rationality' Dimension of Scientific Temper.

\begin{tabular}{|c|c|c|c|c|l|}
\hline Group & N & Mean & SD & $\begin{array}{c}\text { t- } \\
\text { value }\end{array}$ & Significance \\
\hline Rural & 150 & 5.47 & 1.36 & \multirow{2}{*}{2.87} & $\begin{array}{l}\text { Significant at } \\
0.01 \text { level }\end{array}$ \\
\cline { 1 - 3 } Urban & 150 & 6.22 & 1.30 & & \\
\hline
\end{tabular}

The above table shows the mean difference between Rural and Urban senior secondary school students on the rationality dimension of scientific temper. The table reveals that there is no significant mean difference between Rural and Urban senior Secondary school students on rationality dimension. As there was no significant mean difference found between Rural and Urban senior secondary school students on rationality dimension which confirms that Rural and Urban students are equally objective.

Table 5: Significance of difference between Means of Urban and Rural senior Secondary School students on 'Aversion of superstition' Dimension of Scientific Temper.
The above table shows the mean difference between Rural and Urban senior secondary school students on a version of the superstition dimension of scientific temper. The table reveals that there is no significant mean difference between Rural and Urban senior Secondary school students on a version of superstition dimension. As there was no significant mean difference found between Rural and Urban senior secondary school students on a version of superstition dimension which confirms that Rural and Urban students are equally objective.

Table 6: Showing the mean significance difference (Overall dimensions) of scientific temper among rural and urban senior secondary school students (composite score).

\begin{tabular}{|c|c|c|c|c|l|}
\hline Group & N & Mean & SD & value & Significance \\
\hline Rural & 150 & 30.23 & 4.56 & \multirow{2}{*}{7.35} & $\begin{array}{l}\text { Significant at } \\
0.01 \text { level }\end{array}$ \\
\cline { 1 - 3 } Urban & 150 & 34.42 & 5.19 & & \\
\hline
\end{tabular}

The results of above table show the mean difference in rural and urban senior secondary school students to a composite score of scientific temper. The table revealed that there is a significant difference between rural and urban secondary school students to a composite score of scientific temper. 
IJAMSR 2 (1) Www.ijamsr.com CrossRef: https://doi.org/10.31426/ijamsr.2019.2.1.1113

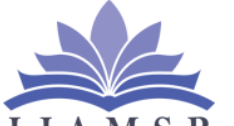

\section{International Journal of Advanced Multidisciplinary Scientific Research (IJAMSR) ISSN:2581-4281}

\section{Conclusion}

a) It was found that $10.25 \%$ were having high Scientific Temper, 60\% were above average Scientific Temper, $13.0 \%$ were average Scientific Temper, 9\% were below average scientific temper and $7.25 \%$ were poor Scientific Temper in rural and urban senior secondary school students.

b) It was found that there is no significant mean difference between rural and urban secondary school student's on the open mindedness dimension of Scientific Temper.

c) It was found that there is a significant mean difference between rural and urban student's on Curiosity, objectivity, rationality and the aversion of the superstition dimension of Scientific Temper.

d) It was found that there is a significant difference between rural and urban senior secondary school student's on Scientific Temper.

\section{Acknowledgments}

The author appreciates all those who participated in the study and helped to facilitate the research process.

\section{Conflict of Interests}

The author declared no conflict of interests.

\section{References}

1) Aasiya Maqbool, Hafiz Mudasir, Andleep Zehta (2014) Scientific Temper of Government and Private Secondary School Students - A Comparative Study. Reports and Opinion 6(1):18-20.

2) Anton E. Lawson (2005). What is the role of induction and deduction in reasoning and scientific inquiry? School of life Science, Arizona state University, Tempe, Arizona 85287-4501.

3) Bhargava P M and Chakrabarti C (2010). Angels, Devil and Science: A Collection of Articles on Scientific Temper, National Book Trust, New Delhi, India.

4) Dubey, K.K., (1992) A study of the scientific temper and it's Measurement, 5th survey of educational Research, P.1240.

5) Dunbay KK (2000) How scientists think in the real world; Implications of science education. Journal of applied develop. Psychology P.49-58.

6) Krishnan, K. And Bhuvaneswari, G. (1990). What does Scientific Temper Mean.? The Educational Review Vol./ XCVL, September 1990, PP.149-150.

7) Nadeem N.A. \& Sabahat (2015).Scientific temper, Career preferences and Academic achievement of rural and urban secondary school students, Department of Education, University of Kashmir, (Unpublished).

8) NCERT (2005). National Curriculum Framework 2005, National Council of Educational Research and Training, New Delhi. 